\title{
Role of Ghrelin in the Regulation of Gastric Acid Secretion Involving Nitrergic Mechanisms in Rats
}

\author{
H. M. BILGIN, C. TUMER, H. DIKEN, M. KELLE, A. SERMET \\ Department of Physiology, Faculty of Medicine, Dicle University, Diyarbakır, Turkey
}

Received March 1, 2007

Accepted May 18, 2007

On-line July 26, 2007

\begin{abstract}
Summary
Ghrelin, an endogenous ligand for growth hormone secretagogue receptor (GHS-R), has been identified in the rat and human gastrointestinal tract. Ghrelin has been proposed to play a role in gastric acid secretion. Nitric oxide (NO) was shown as a mediator in the mechanism of ghrelin action on gastric acid secretory function. However, there is a little knowledge about this topic. We have investigated the role of ghrelin in gastric acid secretion and the role of NO as a mediator. Wistar albino rats were used in this study. The pyloric sphincter was ligated through a small midline incision. By the time, saline $(0.5 \mathrm{ml}$, iv) was injected to the control group, ghrelin ( $20 \mu \mathrm{g} / \mathrm{kg}$, iv) was injected to the first experimental group, ghrelin $(20 \mu \mathrm{g} / \mathrm{kg}$, iv) + L-NAME $(70 \mathrm{mg} / \mathrm{kg}$, $\mathrm{sc}$ ) was injected to the second group and L-NAME (70 mg/kg, sc) was administered to the third group. The rats were killed $3 \mathrm{~h}$ after pylorus ligation; gastric acid secretion, mucus content and plasma nitrite levels were measured. Exogenous ghrelin administration increased gastric acid output, mucus content and total plasma nitrite levels, while these effects of ghrelin were inhibited by applying L-NAME. We can conclude that ghrelin participates in the regulation of gastric acid secretion through NO as a mediator.
\end{abstract}

\section{Key words}

Ghrelin • Acid secretion • Nitric oxide • Rat

\section{Corresponding author}

M. Bilgin, Department of Physiology, Faculty of Medicine, Dicle University, PO Box 21280, Diyarbakır-Turkey. Fax: +90- 4122488440. E-mail: hmbilgin@ dicle.edu.tr

\section{Introduction}

Ghrelin, a 28 amino acid gastric peptide, was found to be a potent releaser of growth hormone and in addition, to participate actively in the control of energy balance and the regulation of food intake (Kojima et al. 1999). Specifically, plasma ghrelin originates in the oxyntic gland where A-like cells exist and is secreted into the bloodstream. Lower concentrations have also been reported at various regions in the body (Jeffery et al. 2002, Volante et al. 2002, Gaytan et al. 2003). It is well known that many gastrointestinal peptides participate in the regulation of gastric functions and ghrelin receptors are abundant in the gastrointestinal tract including the pancreas in both rodents and man. Ghrelin has also been proposed to influence gastric acid secretion (Date et al. 2001). Thus, it is possible to speculate that ghrelin may play a role in the regulatory mechanism of acid secretion in the stomach.

Nitric oxide (NO) plays an important role in the regulation of various cellular functions including those of the gastrointestinal tract (Moncada et al. 1991) and it has been suggested that NO augments the release of mucus in stomach (Brown et al. 1992). On the other hand, it was reported that inhibition of NO by nitric oxide synthase (NOS) inhibitors decreased acid secretion in mice and dogs (Bilski et al. 1994, Hasebe et al. 1998). The NO pathway is thought to be involved in promotion of gastric acid secretion through ECL (enterochromaffin-like) cells (Hasebe et al. 2001).

The role of ghrelin in the mechanism of gastric secretion and gastroprotection has been little investigated, but Sibilia et al. (2003) showed that central administration of ghrelin exerts gastroprotection 
and this effect is attenuated by the blockade of nitric oxide synthase (NOS) activity with L-NAME (N-nitroL-arginine methyl ester) suggesting that NO may play an important role in this protection. Intracerebroventricular (icv) and intravenously (iv) administered ghrelin to rats is shown to stimulate gastric acid secretion, while ghrelin administered subcutaneously exerted no effect on gastric acid secretion (Masuda et al. 2000, Sibilia et al. 2002). As NO releasing drugs have protective effects against mucosal injury and the NO system is modulated by synthetic GHS-R agonists, an interactive role of ghrelin and NO in controlling gastric mucosal blood flow may well be hypothesized.

Thus, the objective of the present study was 1) to evaluate the effects of ghrelin administration on gastric acid secretion and mucus content, and 2) to examine the involvement of NO system in ghrelininduced acid secretion in the animals pretreated with ghrelin.

\section{Methods}

\section{Animals}

Male Wistar Albino rats weighing 200-250 g (Dicle University Research Center, Diyarbakır, Turkey) were housed in single cages that had wirenet bottoms. The animals were deprived of food for $24 \mathrm{~h}$ but allowed free access to water up to the beginning of the experiments. Animals were divided into four groups as control and three experimental groups. Eight animals were taken in each group. All procedures were carried out in accordance with the "Guidelines for the use of animals in medical research".

\section{Experimental protocol}

Gastric secretory volume and acid output measurements were performed by the pyloric ligation method (Alumets et al. 1982). Under light ether anesthesia, the pyloric sphincter was ligated through a small midline incision and the abdominal wall was closed. At the time of pyloric ligation, saline $(0.5 \mathrm{ml}$, iv) was injected to the control group, ghrelin $(20 \mu \mathrm{g} / \mathrm{kg}$, iv) was injected to the first experimental group, the second experimental group received both ghrelin $(20 \mu \mathrm{g} / \mathrm{kg}$, iv) and L-NAME (70 $\mathrm{mg} / \mathrm{kg}, \mathrm{sc}), \mathrm{L}-\mathrm{NAME}(70 \mathrm{mg} / \mathrm{kg}, \mathrm{sc})$ was injected to the third group. The rats were awake within $5 \mathrm{~min}$ after pylorus ligation and freely moving. They were killed $3 \mathrm{~h}$ after pylorus ligation and their stomachs were removed.

\section{Measurement of gastric acid secretion}

The gastric content of rats was collected and centrifuged. After measuring the volume of gastric secretions, gastric acid output was determined by titration of samples with $0.01 \mathrm{M} \mathrm{NaOH}$ to $\mathrm{pH} 7.0$ using phenolphthalein $(2 \%)$ as an indicator. Acid output was calculated by multiplying the volume of gastric juice by the acid concentration. Acid output was expressed in micromoles per $3 \mathrm{~h}$ period.

\section{Gastric adhesion mucus content}

Gastric adhesion mucus content was determined by the Alcian blue method (Qiu et al. 1996). The stomachs were removed, opened, and immediately soaked in Alcian blue solution for $2 \mathrm{~h}$. The Alcian blue dye complex attached to the gastric wall mucus and was separated from gastric wall by vortexing and subsequent extracting with magnesium chloride. The extracted solution was quantitated spectrophotometrically at 598 $\mathrm{nm}$. The mucus content was correlated with the amount of Alcian blue per gram wet weight of glandular tissue.

\section{Measurement of plasma levels of nitrit}

Since NO is a very labile molecule, its direct measurement in the biological samples is very difficult. In an aqueous solution, NO reacts with molecular oxygen and accumulates in the plasma as nitrite and nitrate ions. Therefore, the stable oxidation end-products of $\mathrm{NO}$, nitrite $\left(\mathrm{NO}_{2}{ }^{-}\right)$and nitrate $\left(\mathrm{NO}_{3}{ }^{-}\right)$, can be readily measured in biological fluids and have been used in vitro and in vivo as indicators of NO production. Plasma nitrite levels were measured with the Griess reaction (Cortas and Wakid 1990). Reduction of nitrate to nitrite was accomplished by catalytic reaction using cadmium. The nitrite produced was determined by diazotisation of sulfanilamide and coupling to naphthylethylene diamine. Absorbance of this complex was measured at $545 \mathrm{~nm}$. A standard curve was established with a set of serial dilutions $\left(10^{-8}-10^{-3} \mathrm{~mol} / \mathrm{l}\right)$ of sodium nitrite. Linear regression was made by using the peak area from the nitrite standard. The resulting equation was then used to calculate the unknown sample concentrations. Results were expressed as $\mu$ moles per liter plasma.

\section{Drugs}

Synthetic rat ghrelin and ghrelin kit were produced by Phoenix Pharmaceuticals, (CA., USA). L-NAME were purchased from Sigma Chemical (St. Louis, MO., USA). Ghrelin and L-NAME were dissolved in saline, immediately before use. 


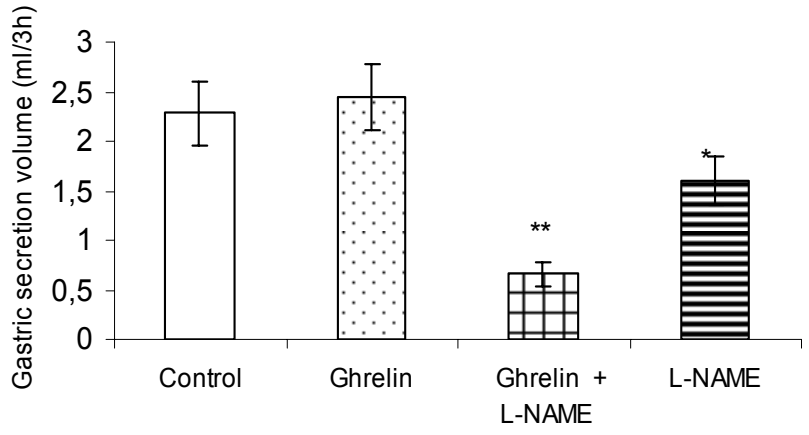

Fig 1. Effects of ghrelin $(20 \mu \mathrm{g} / \mathrm{kg})$, L-NAME $(70 \mathrm{mg} / \mathrm{kg}$, s.c.) and ghrelin + L-NAME on gastric secretion volume in pylorus-ligated rats. Each bar represents the mean \pm S.E.M. of eight rats per group. $* p<0.05, * * p<0.01$ vs. control.

\section{Statistical analysis}

All data are presented as mean \pm S.E.M. Differences between groups were assessed by one-way analysis of non-parametric Kruskal-Wallis test followed by Mann Whitney $U$ test. A value of $p<0.05$ was considered statistically significant.

\section{Results}

\section{Determination of gastric secretion volume}

The effect of ghrelin on acid secretion was studied. As shown in Figure 1, intravenous administration of ghrelin $(20 \mu \mathrm{g} / \mathrm{kg})$ constituted a slight increase at gastric acid volume from $2.28 \pm 0.32 \mathrm{ml} / 3 \mathrm{~h}$ to $2.44 \pm 0.33$ $\mathrm{ml} / 3 \mathrm{~h}$ but the increase at the secretion volume was not statistically significant. In contrast, we observed a marked decrease at ghrelin+L-NAME (70 $\mathrm{mg} / \mathrm{kg})$ group as $0.66 \pm 0.12 \mathrm{ml} / 3 \mathrm{~h}$.

Gastric acid output in response to ghrelin and ghrelin+ L-NAME administration

The results showed that exogenous ghrelin $(20 \mu \mathrm{g} / \mathrm{kg}$, iv) administration exerted a stimulatory effect on gastric acid output while ghrelin + L-NAME $(70 \mathrm{mg} / \mathrm{kg}$, sc) injection constituted a significant inhibitory activity. As illustrated in Fig. 2, the increase in acid output was from $157 \pm 20 \mu \mathrm{Eq} / 3 \mathrm{~h}$ to $281 \pm 65 \mu \mathrm{Eq} / 3$ $\mathrm{h}$, while it reached to a lower value of $51 \pm 8 \mu \mathrm{Eq} / 3 \mathrm{~h}$ at ghrelin + L-NAME group and $45 \pm 6 \mu \mathrm{Eq} / 3 \mathrm{~h}$ at L-NAME group.

\section{Effects of exogenous ghrelin on plasma nitrite levels}

Plasma nitrite levels at ghrelin group were elevated after ghrelin administration at a dose of $20 \mu \mathrm{g} / \mathrm{kg}$ (Fig. 3), while it showed a decrease at ghrelin + L-NAME

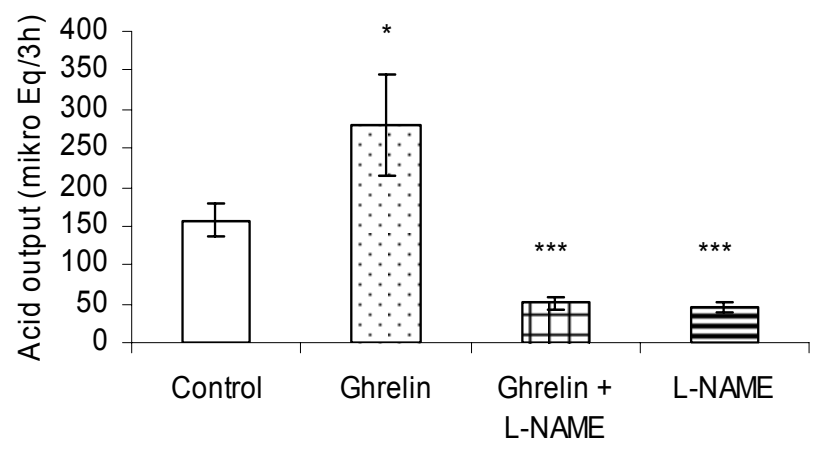

Fig 2. Effects of ghrelin $(20 \mu \mathrm{g} / \mathrm{kg})$, L-NAME ( $70 \mathrm{mg} / \mathrm{kg}$, s.c.) and ghrelin + L-NAME on gastric acid output in pylorus-ligated rats. Each bar represents the mean \pm S.E.M. of eight rats per group. $* p<0.05, * * p<0.001$ vs. control.

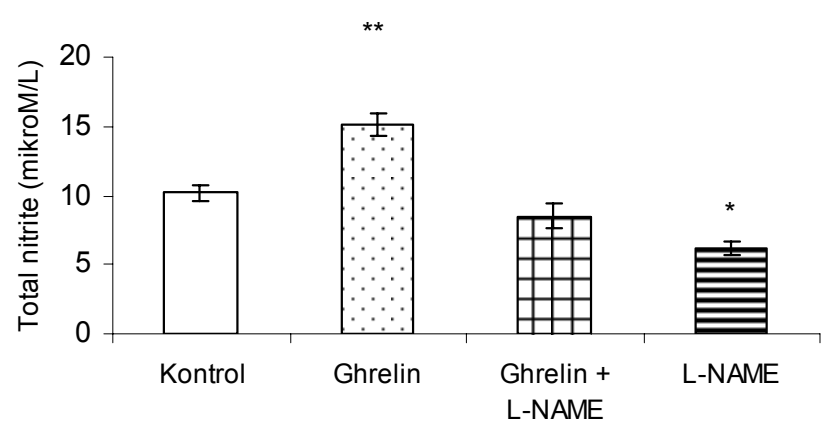

Fig 3. Effects of ghrelin $(20 \mu \mathrm{g} / \mathrm{kg})$, L-NAME (70 mg/kg, s.c.) and ghrelin + L-NAME on plasma total nitrite levels in pylorus-ligated rats. Each bar represents the mean \pm S.E.M. of eight rats per group. $* p<0.05, * * p<0.01$ vs. control.

(70 $\mathrm{mg} / \mathrm{kg}$ ) group. In animals that received ghrelin, the value was $15.13 \pm 0.79 \mu \mathrm{mol} / 1$, while it showed a significant decrease at ghrelin + L-NAME and L-NAME group as $8.50 \pm 0.87$ and $6.2 \pm 0.45$, respectively.

\section{Effects of exogenous ghrelin on gastric mucus content}

As shown in Figure 4, the increase of gastric mucus content at ghrelin group was significantly reduced at ghrelin + L-NAME group. The values of gastric mucosal adherent mucus concentration in ghrelin-treated rats were $314 \pm 19 \mu \mathrm{g} / \mathrm{g} /$ tissue while there was a decrease at ghrelin + L-NAME group $(191 \pm 10 \mu \mathrm{g} / \mathrm{g} / \mathrm{tissue})$. In addition, the results that the increased secretion of mucus by ghrelin were significantly reduced by L-NAME as $150 \pm 10 \mu \mathrm{g} / \mathrm{g} /$ tissue suggesting that the role of NO could be related via synthesis and secretion of mucus.

\section{Discussion}

In the present study, we examined the effects of ghrelin on gastric acid secretion and aimed to evaluate the 


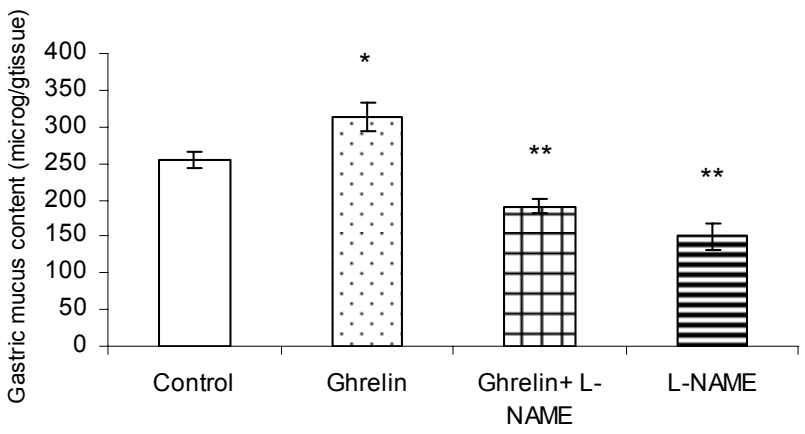

Fig 4. Effects of ghrelin $(20 \mu \mathrm{g} / \mathrm{kg})$, L-NAME (70 mg/kg, s.c.) and ghrelin+L-NAME on gastric mucus content in pylorus-ligated rats. Each bar represents the mean \pm S.E.M. of eight rats per group. $* p<0.05,{ }^{* *} p<0.01$ vs. control.

role of NO in this mechanism. We used L-NAME for this purpose because it was demonstrated that nitric oxide was involved in the regulation of acid and alkaline secretion (Takeuchi et al. 1997). The results of secretory studies performed on pylorus-ligated rats were evaluated.

We demonstrated that intravenous injection of ghrelin stimulates gastric acid secretion. This observation is in accordance with the findings of earlier studies (Masuda et al. 2000, Date et al. 2001, Brzozowski et al. 2004, Mori et al. 2006) which also demonstrated an increase in the gastric acid secretion after administration of ghrelin. The secretatory effect of ghrelin was abolished by an inhibitor of NOS, L-NAME. We postulate that the inhibitory effect of L-NAME on gastric acid secretion is possibly related to local gastric ischemia. In contrast, the inhibitory effect of intracerebroventricular application of ghrelin on acid secretion at pylorus-ligated rats was also observed (Sibilia et al. 2002). This seems reasonable as in this setting the route of ghrelin administration was different. It was also reported that ghrelin has no effect on gastric acid output (Dornonville et al. 2004) and on acid secretion (Levin et al. 2005) in rats. These different results could be ascribed to the use of different methods as the studies of gastric acid secretion began 7-10 days after surgery, pentobarbital and isoflurane was used to perform anesthesia and the acid was collected in $30 \mathrm{~min}$ by using a plastic gastric fistula.
It has been suggested that endogenously generated or exogenously added NO protects gastric mucosa against damage induced by various types of insult (Masuda et al. 1995). The implication of NO in gastroprotection induced by ghrelin was determined by employing an inhibitor of NOS, L-NAME and by nitrite/nitrate assay in gastric lumen. The gastric mucus content and total nitrite levels were increased by ghrelin administration, while it was decreased by treating ghrelin+L-NAME. Thus, our data indicated that the gastroprotective effect of peripherally administered ghrelin appeared to be mediated by NO pathway. Such gastroprotective effect of ghrelin can be attenuated by pretreatment with L-NAME suggesting the involvement of NO pathway in this effect (Sibilia et al. 2003). L-NAME reduced the acid secretion probably because of a decreased mucosal blood flow. It was reported that endogenous NO is involved in an increase of postprandial acid secretion in humans (Konturek et al. 1999). It was also showed that intracerebroventricular administration of ghrelin increased NOS levels in the hypothalamus and the administration of NOS inhibitor, L-NAME blocked ghrelin-induced feeding (Gaskin et al. 2004). This shows a possible pathway for the effects of ghrelin which appears to be operating through NO and its effects are altered by L-arginine analogs. Thus NO seems to be involved in the promotion of gastric acid secretion under physiological conditions and the suppression of NO exerts an inhibitory influence on gastric acid secretion.

In conclusion, these results suggest that ghrelin has a major impact on gastrointestinal regulatory systems. The findings of our study demonstrate that ghrelin is a peptide which plays a stimulatory role in the regulation of gastric acid secretion and mucus secretion while these effects can be abolished by a NOS inhibitor, L-NAME. Further investigations are needed for the evaluation of these regulatory mechanisms of ghrelin.

\section{Conflict of Interest}

There is no conflict of interest.

\section{References}

ALUMETS J, EKELUND M, HAKANSON R, HEDENBRO J, REHFELT JF, SUNDLER F, VALLGREN S: Gastric acid response to pylorus ligation in rats: is gastrin or histamin involved? J Physiol Lond 323: 145-156, 1982.

BILSKI J, KONTUREK SJ, CIESZKOWSKI M, PAWLIK WW: Endogenous nitric oxide in the regulation of gastric acid secretion, gastrin release and blood flow. Biomed Res 15 (Suppl 2): 63-67, 1994. 
BROWN JF, HANSON PJ, WHITTLE BJ: Nitric oxide donors increase mucus gel thickness in rat stomach. Eur $J$ Pharmacol 223: 103-104, 1992.

BRZOZOWSKI T, KONTUREK PC, KONTUREK SJ, KWIECIEN S, DROZDOWICZ D, BIELANSKI W, PAJDO R, PTAK A, NIKIFORUK A, PAWLIK WW, HAHN EGl: Exogenous and endogenous ghrelin in gastroprotection against stress-induced gastric damage. Regul Peptides 120: 39-51, 2004.

CORTAS NK, WAKID NW: Determination of inorganic nitrate in serum and urine by a kinetic cadmium-reduction method. Clin Chem 36: 1440 -1443, 1990.

DATE Y, NAKAZATO M, MURAKAMI N, KOJIMA M, KANGAWA K, MATSUKURA S: Ghrelin acts in the central nervous system to stimulate gastric acid secretion. Biochem Biophys Res Commun 280: 904-907, 2001.

DORNONVILLE DE LA COUR C, LINDSTROM E, NORLEN P, HAKANSON R: Ghrelin stimulates gastric emptying but without effect on acid secretion and gastric endocrine cells. Regul Pept 120: 23 -32, 2004.

GASKIN FS, FARR SA, WILLIAM A, BANKS WA, KUMAR VB, MORLEY JE: Ghrelin-induced feeding is dependent on nitric oxide. Peptides 24: 913-918, 2004.

GAYTAN F, BARRERIO ML, CHOPIN LK, HERINGTON AC, MORALES C, PINILLA L, CASANUEVA FF, AGUILAR E, DIEGUEZ C, TENA SEMPERE M: Immunolocalization of ghrelin and its functional receptor, the type Ia growth hormone secretagogue receptor, in the cyclic human ovary. J Clin Endocrinol Metab 88: 879-887, 2003.

HASEBE K, HORIE S, YANO S, WATANABE K: Inhibitory effect of $\mathrm{N}^{\mathrm{w}}$ - nitro-L-arginine on gastric secretion induced by secretagogues and vagal stimulation in the isolated stomach. Eur J Pharmacol 350: 229-236, 1998.

HASEBE K, HORIE S, KOMASAKA M, YANO S, WATANABE K: Stimulatory effects of nitric oxide donors on gastric acid secretion in isolated mouse stomach. Eur J Pharmacol 420: 159-164, 2001.

JEFFERY PL, HERINGTON AC, CHOPIN LK: Expression and action of the GHR peptide ghrelin and its receptor in prostate cancer cell lines. $J$ Endocrinol 172: 7-11, 2002.

KOJIMA M, HOSODA H, DATE Y, NAKAZATO M, MATSUO H, KANGAWA K: Ghrelin is a growth-hormonereleasing acylated peptide from stomach. Nature 402: 656-660, 1999.

KONTUREK JW, FISCHER H, GROMOTKA PM, KONTUREK SJ, DOMSCHKE W: Endogenous nitric oxide in the regulation of gastric secretory and motor activity in humans. Aliment Pharmacol Ther 13: 1683-1691, 1999.

LEVIN F, EDHOLM T, EHRSTROM M, SCHMIDT PT, KIRCHGESSNER AM, HILSTED HM, HELLSTROM PM, NASLUND E: Effect of peripherally administered ghrelin on gastric emptying and acid secretion in the rat. Regul Pept 131: 59-65, 2005.

MASUDA E, KAWANO S, NAGANO K: Endogenous nitric oxide modulates ethanol-induced gastric mucosal injury in rats. Gastroenterology 108: 58-64, 1995.

MASUDA Y, TANAKA T, INOMATA N, OHNUMA N, TANAKA S, ITOH Z: Ghrelin stimulates gastric acid secretion and motility in rats. Biochem Biophys Res Commun 276: 905-908, 2000.

MONCADA S, PALMER RMJ, HIGGS EA: Nitric oxide: physiology, pathophysiology and pharmacology. Pharmacol Rev 43: 109-142, 1991.

MORI M, SUZUKI H, MASAOKA T, IMAEDA H, NOMOTO Y, HOSODA H, NISHIZAWA T, KANGAWA K, HIBI T: Intravenous ghrelin administration enhances gastric acid secretion - evaluation using wireless $\mathrm{pH}$ capsule. Aliment Pharmacol Ther 24 (Suppl 4): 96-103, 2006.

QIU BS, PFEIFFER CJ, CHO CH: Effects of chronic nitric oxide synthase inhibition in cold-restraint and ethanolinduced gastric mucosal damage in rats. Digestion 57: 60-66, 1996.

SIBILIA V, PAGANI F, GUIDOBONO F, LOCATELLI V, TORSELLO A, DEGHENGHI R, NETTI C: Evidence for a central inhibitory role of secretagogues and ghrelin on gastric acid secretion in conscious rats. Neuroendocrinology 75: 92-97, 2002.

SIBILIA V, RINDI G, PAGANI F, RAFETTI D, LOCATELLI V, TORSELLO A: Ghrelin protects against ethanolinduced gastric ulcers in rats: studies on the mechanisms of action. Endocrinology 144: 353-359, 2003.

TAKEUCHI K, KATO S, YASUHIRO T, YAGI K: Mechanism of acid secretory changes in rat stomach after damage by taurocholate: role of nitric oxide, histamine and sensory neurons. Dig Dis Sci 42: 645-653, 1997. 
VOLANTE M, ALLIA E, GUGLIOTTA P, FUNARO A, BROGLIO F, DEGHENGHI R, MUCCIOLI G, GHIGO E, PAPOTTI M: Expression of ghrelin and GHS receptor by pancreatic islet cells and related endocrine tumors. J Clin Endocrinol Metab 87: 1300-1308, 2002. 